\title{
Management of Forests in the Northern Western Ghats
}

\author{
Ketaki Ghate \\ (The author is Founder and Managing partner at oikos for ecological services, Trustee at \\ Ecological Society, Member - JFM committee for Bambhurda hills, Pune, \\ Visiting faculty at BN College for Master of Architecture.)
}

\begin{abstract}
The Western Ghats in India are a UNESCO World Heritage Site and one of the "hotspots" of biological diversity in the world. Looking at the physiography and climate of the Northern Western Ghats, the region should support Tropical semi evergreen (on Crestline) to moist deciduous type of forest (on Eastern end of spurs) as 'climax' type of vegetation. But it is seen to be variedly degraded and fragmented due to use by local people for cultivation or intrusion by outsiders for commercial gains over the last two centuries, as well as modern developmental pressures within the last few decades. The original forest cover and biodiversity is seen only in pockets of notified protected areas or within semiprotected areas like scared groves. Rest of the landscape is degraded to various seral stages depending on the degree of disturbance and is reflected in six major vegetation classes namely Rocky outcrops, Open grasslands with Scrub, Dense shrubbery, Dwarf canopy forests, Riparian forests and Tall mature forests. Composition of species pertaining to each of these classes is more or less definite with some overlaps. The current article tries to illustrate the reasoning for each of these stages along with the dominant species associated with each stage, mainly flora and birds. Of these stages, the last one is the protected 'climax' vegetation, which is the only support for 'habitat specialist' species, some of which are threatened as per IUCN. No other seral stage can support this biodiversity. From an ecological point of view, there is an urgent need to conserve these pockets and provide buffer for them. A detailed study may need to be undertaken to know the exact areas under such climax forest and develop a policy for their protection.

The article also suggests landscape-based management strategies for conservation in the Northern Western Ghats, based on ecological role and potential of each land class. This can be achieved through various restoration techniques like soil water conservation, plantation, habitat development etc.

Keywords : Western Ghats, Forests in India, Landscape-based management, Ecological Restoration
\end{abstract}

\section{Forests in Northern Western Ghats and their ecological significance}

The Western Ghats is a mountain range that runs along the west coast of India right from Vindhya Satpuda in the North till Kanyakumari in the South covering about $1600 \mathrm{~km}$ in length. The part of Western Ghats in Maharashtra is popularly known as Sahyadri. Due to its physiographic and climatic conditions, this part supports "Tropical semi evergreen type of forest" (Champion \& Seth, 2005) but due to years of human intervention and other biotic interventions, this mountain range is variedly degraded and fragmented.

The most important aspect which needs to be considered in case of the Northern Western Ghats (NWG) is the 'fragility of ecosystem' shaped due to climate, especially along the main crest line. The western escarpment receives the full force of southwest monsoon resulting in heavy rainfall and dense fog during rainy season. Due to severity of climatic and erosional processes, the ecosystems of this region may be called 'fragile'. Due to prevailing specialized conditions, life forms adapted to such conditions may not be able to survive if their niches are disturbed in any way. Similarly, life forms from outside the region may not be able to replace native life forms or colonise due to their inability to adapt to such specialized conditions. This region, when disturbed, thus suffers on two counts. That is why it 


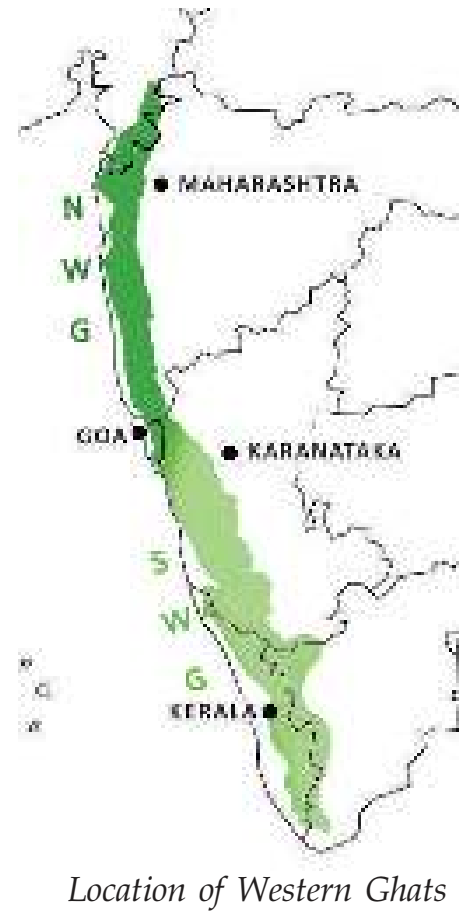

should be treated as a fragile zone. (Gole, Survey of birds of Bhimashankar wildlife sanctuary and formulation of managment guidlines for their protection, 2000)

Physical features of this range are also very important. This mountain range also serves as catchment to all major rivers feeding the entire Indian peninsula. Looking at the river ecology, physical conditions (abiotic conditions) and forests (biotic resources) near the source shape the quality of water to a great extent. Also these are the major soil producing areas, supplying soil to downstream. Due to high rainfall, processes of soil formation are relatively faster than low rainfall areas on plains, though happening at geological time scale.

All these special physical features have created unique habitats which have been supporting endemic

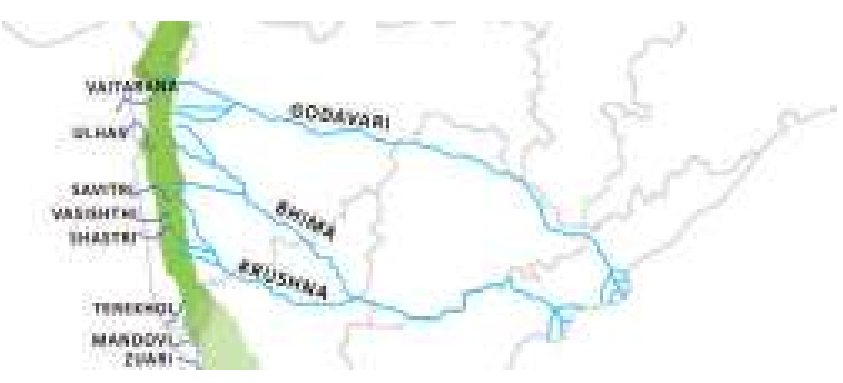

Rivers originating in NWGs
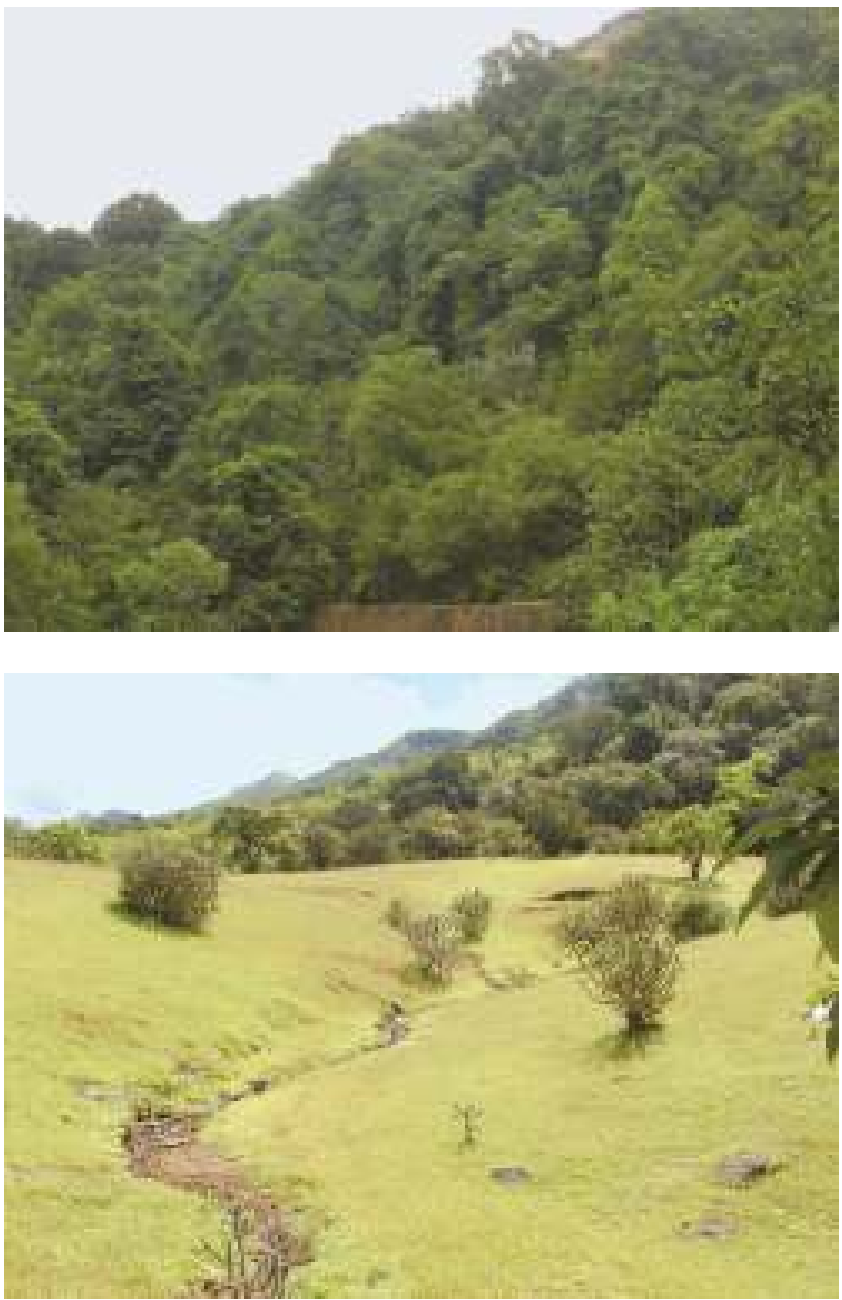

Above: Tropical semi evergreen forests on slopes, Koyna. Below : Forests Degraded to open grassland with scrub, Mulshi.

biodiversity. With the background of fragile ecosystems, this biodiversity happens to be extremely important and precious. Though the complete WGs area covers barely five percent of India's land, $27 \%$ of all species of higher plants in India $(4,000$ of 15,000 species) are found here, of which nearly 1800 are endemic. This is why it was declared as biodiversity hotspot (Norman, Meittermeir, Meittermeir, da Fonseca \& Kent, 1999). But this very fact is neglected by current developmental trends and government policies. Pressures in these areas have been increasing since last few decades. The specialist biodiversity is disappearing very fast and being threatened day by day.

Various anthropogenic activities, both traditional and modern, have been degrading the forests in WGs. 

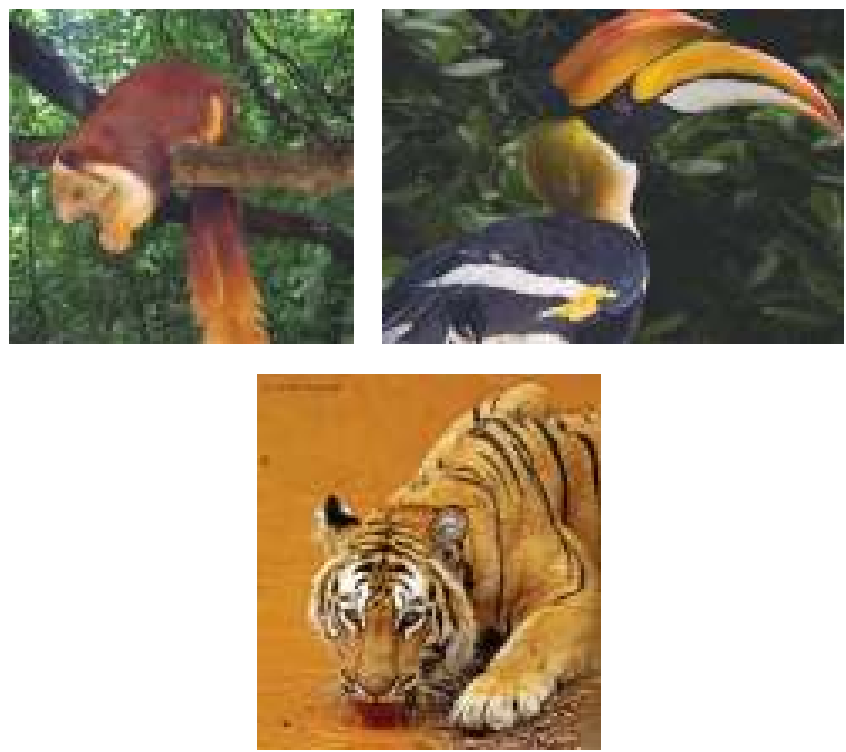

Threatened biodiversity from NWGs - Malabar Giant Squirrel, Great pied Hornbill, Royal Bengal Tiger.

Glimpses of the original landscape are seen in the form of a few sacred groves and protected or inaccessible forest patches. These are the only patches left in the landscape which support fragile biodiversity. A few of these areas are so sensitive that if disturbed, those species are likely to get extinct. So these patches have got biodiversity heritage value. Looking at the developmental trends in the surrounding landscape, such areas need buffer for its long term survival and need proper management to let the humans enjoy those resources in long run. Another very significant aspect of these patches is they serve as reference ecosystem which gives a definite direction to evolve a management plan to restore forests in this landscape.

Along with the ecological services provided in terms of soil and water, Western Ghats also support livelihood of tribals, through native biodiversity and forest products in terms of timber, fruits, nuts, oil, vegetables, medicines, honey, wax, gum etc.

\section{Current status}

Current status of the landscape of Western Ghats is the outcome of years of use by local people since last two centuries, as well as modern developmental pressures within the last few decades. The analysis of current status begins with the overview of sociocultural history. To know the earlier history one has to read through older literature like gazetteers or talk to elderly experts and researchers. After a brief study, it can be said that environmental history of this region can be traced back to 1830s.

For many years after the beginning of British rule in this region (1818), the comparatively small population and the limited area under tillage made any special measures for preserving forests unnecessary. Forests were in quite a healthy state along with apex species of animals like tigers and panthers. In 1855 General Davison, a British executive, shot bears and panthers within a few miles of Poona. (Gazeteer department, 1885)

Clearing the large area under trees and brushwood for tillage was one of the most pressing administrative questions of the time. It was mainly with this objective that when (1836-37) the revenue survey was introduced into the west of the Pune district, almost all hill-sides were divided into plots and offered at little more than nominal rents. About twenty years later, the population had greatly increased. After the railway was opened through the Bor pass, the great demand for wood and the ease with which it could be sent to market were rapidly stripping the area of trees. (Gazeteer department, 1885). This documentation is supposedly the first record to document the cutting of primary forest in the NWG region.

Even then, passive conservation was happening by local communities due to taboos, right to use specific patches of forests by specific castes etc. Tradition of preserving sacred groves was one of the most important practices from the ecological point of view. It is followed by the locals even today.

In $20^{\text {th }}$ century, modern water management was initiated by the British rulers in the form of large dams. This was continued even after India achieved its independence. Today, almost all rivers originating on the crest line of Western Ghats and flowing towards East are dammed, either for power generation or irrigation. So the original landscape with intact river courses is hardly seen anywhere. Repercussions of these man-made changes on the ecosystems were manifold. Of late, doubt has been cast on the quality of benefits that accrue from such projects. (Gadgil, 1979)

Due to the backwaters of these dams, settlements along rivers, fertile paddy fields, and the forests on lower slopes got submerged. Local people were given compensatory land somewhere towards east of the districts within NWGs (mainly Pune, Satara, Kolhapur) in low rain fall areas. Many of them were not ready to move out, so they shifted to upper contours and formed new settlements i.e. wadi. Those who had moved out and couldn't acclimatize to the new lifestyle also returned and joined others. Now 
that these people had lost their fertile land, they had to cultivate on slopes. First, the forest was slashed and burnt to make the land patches appropriate for cultivation. They started cultivating hill millets (namely Nachani, Varai and Teel) consecutively for three years. But slopes being inappropriate for cultivation and yielding persistent production, they had to leave this patch fallow after three years, i.e. let it rest for few years to allow nutrients to be put back into the soil, while the vegetation grew. They had to shift to new patches on the slopes. Eventually all the forested slopes were degraded to secondary vegetation. The rich wildlife including Sambar, Barking deer and Wild boar was threatened with loss of tree cover and accessibility to urban poachers (Gadgil, 1979). This practice has continued till today, as seen in catchments of all dams or rivers located within NWGs, to name a few, Mulshi, Varasgaon, Panshet, Radhanagari etc.

Add to this other biotic pressures namely grazing

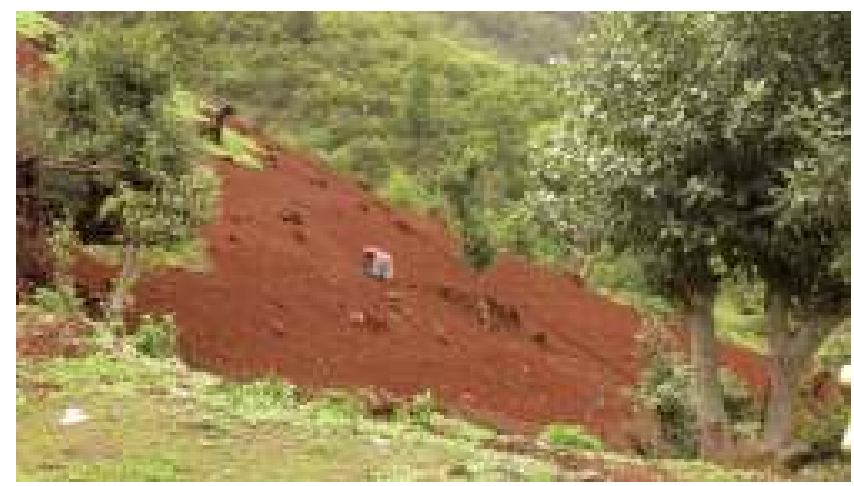

Shifting cultivation patch near Rajgad Fort

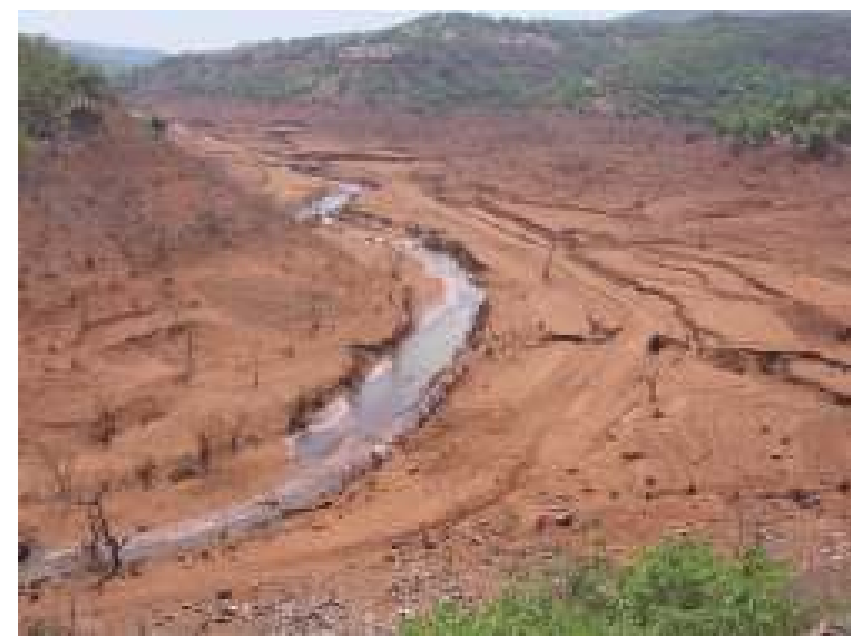

Exposed areas, Neera Deoghar dam, Bhor and cutting for fuel wood. Cattle of local people freely roam all over the slopes (including steep slopes) eating up tender regeneration which would have formed the future forest. Trampling also leads to soil hardening and degradation of soil quality. Selective cutting for fuel wood and harvesting of specific food
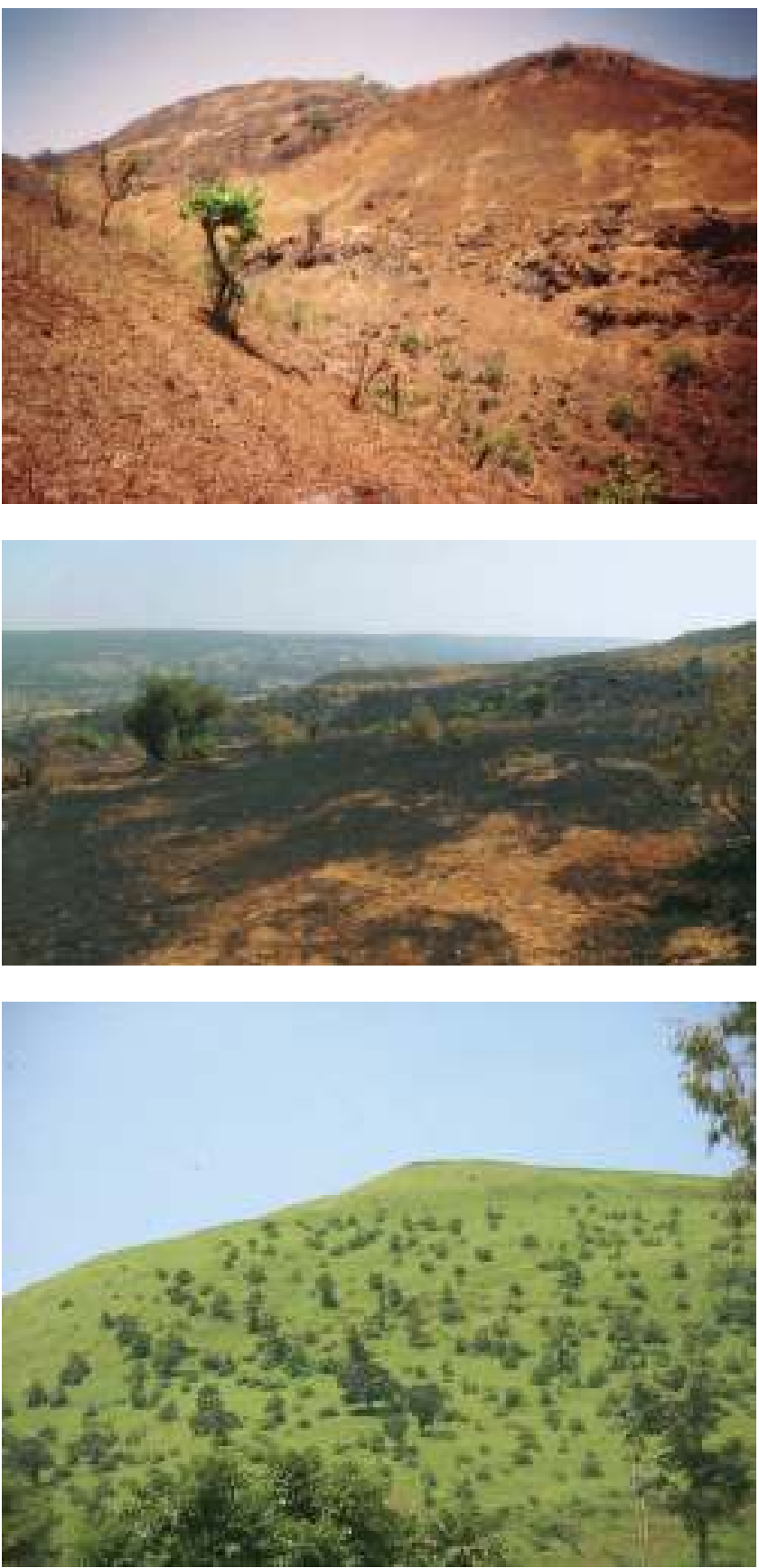

Effect of various stresses like shifting cultivation, fire, grazing leading to degraded landscape without forests at Varasgaon and Bhor Catchment 
crops has also been changing the composition and density of forests. Few species of Ceropegia, one of the plant species, being harvested for its edible tubers, are extinct or threatened just because it is harvested at a tender stage, much before flowering and fruiting
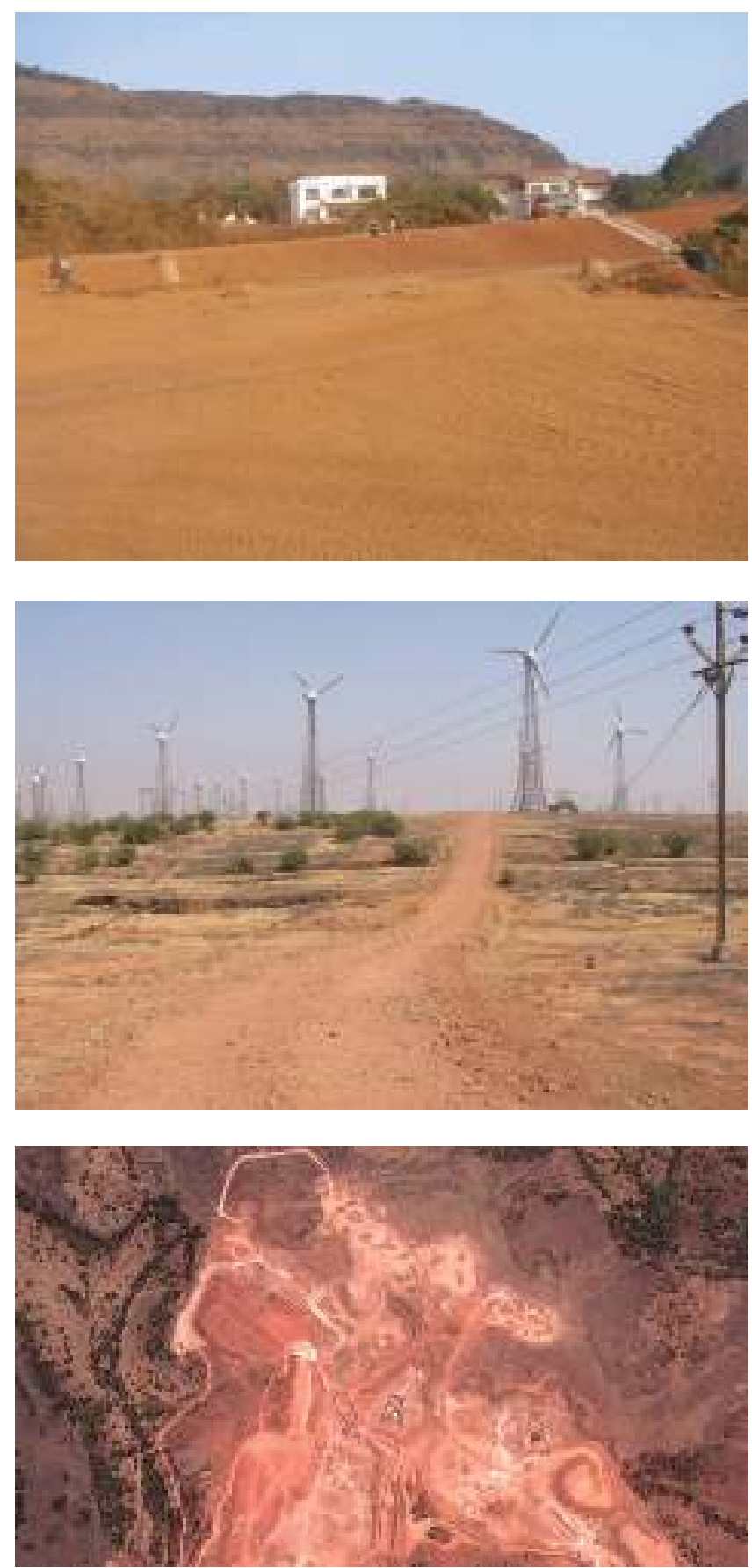

Effects of modern development like farm house scheme, wind mills and bauxite mining @ Mulshi catchment, Koyna catchment and District Kolhapur
(Negi, 1993) (KSR Murthy, 2012). This actually stops its natural spread by seeds.

Fire is another significant threat to entire NWGs. It must be noted that it's not a natural fire, but it is set deliberately or set due to ignorance by local people. It obviously arrests natural succession of secondary vegetation i.e. degraded ecosystem towards mature ecosystem. Moist deciduous vegetation with dominant Terminalias is not able to progress towards evergreen vegetation due to regular fires, all over the NWGs.

All of the above practices have been causing forest fragmentation in Northern Western Ghats, which has caused loss of habitat for specialist or indicator species and displacement of such biodiversity. Forest fires, fragmentation and their synergisms may be driving deforestation processes that are fundamentally altering landscapes and biodiversity in WGs. (Kodandapani, Cochrane, \& Sukumar, 2004). The specialist species prevalent earlier, are being replaced by generalist or common species. Many species are getting threatened day by day. To name a few - bird species like Great pied Hornbill, Forest Owlet, Oriental dwarf Kingfisher, Mammals like Giant squirrel, Mouse Deer, are now most rare species from NWGs.

Another very significant threat to the Northern Western Ghats is that of modern development sprawling on the hill slopes in the form of farm house project schemes, new "hill stations", new roads, widening of existing roads, industrial complexes, or township development. Slopes are terraced with the help of excavators. All earlier vegetation is removed being irrelevant to the urban man. New non-native species of plants are planted to recreate the greenery. This is weakening the already fragile ecosystems. Fragmentation of landscape is accelerated at a rate never before earlier. The changes which took place in

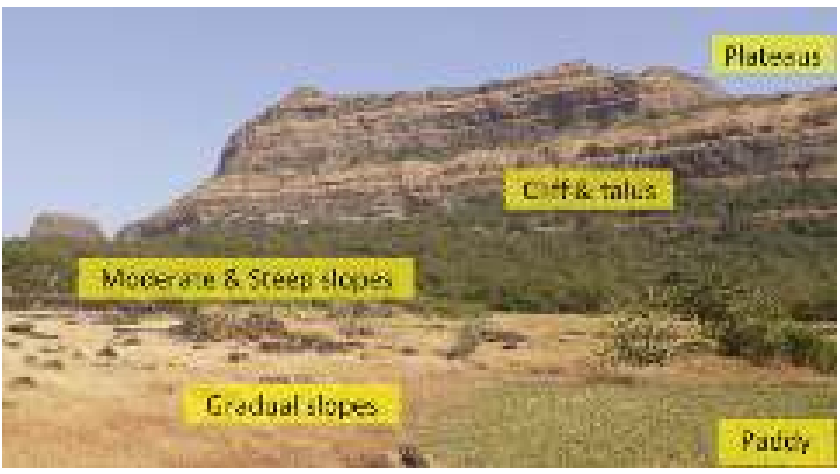

Representative land classes in NWGs 
last two centuries have accelerated many times just within the last two decades. Big projects like mining, wind mills, etc. are also threatening the ecosystem structure and increasing its vulnerability.

To summarize the earlier two sections, it can be said that landscape in Northern Western Ghats should support semi-evergreen type of forest. But years of human interference have degraded it to various levels depending on intensity of the activities. This interference is many times governed by land classes and its accessibility. This is how the present quality (or structure) of landscape is reached.

Broadly, across the entire Northern Western Ghats, the following main land classes are observed -

Paddy, Gradual slopes, Steep slopes, Cliff or Cliffside rock fall areas and Plateaus.

1. Paddy - This is found in the flat terrain mostly in the valley bottom or on plateaus at various levels. This is a modified land class. Mostly stream sides are made into terraces or even instream terraces are formed. Settlements are also seen nearby these paddy fields.

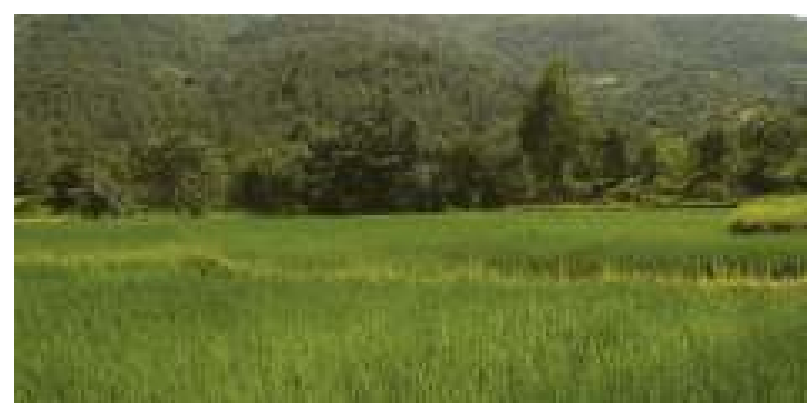

Paddy, Bhor catchment

2. Gradual Slopes - Behind the paddy start gradual slopes, which have been slashed and burnt regularly for shifting cultivation of Hill millets. So

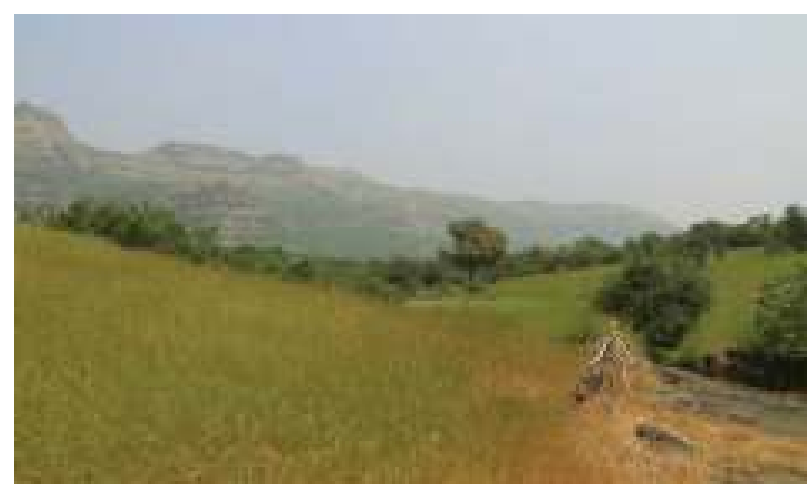

Open Gradual slopes@ Mulshi these gradual slopes are degraded to open grasslands or scrub. This is because, being easily accessible, these slopes have experienced many cycles of shifting cultivation. Due to a short fallow period, the ecosystem couldn't reach back to the state of developing a forest cover. Also, being near the villages, fuel wood extraction has been a regular practice, so was grazing by cattle. Due to all these factors these slopes are under continuous stress and so the stage of open patches with grasslands is arrested since many years.

3. Steep slopes - Slopes leading towards tops have moderate to steep gradients. These were also cultivated till few years back until 1990s. But villagers stopped cultivating here due to various reasons : either they sold these lands or migrated to cities in search of jobs. Those staying in villages are not capable of cultivating larger lands on slopes. The result of this change is semi-protected areas with dense shrubbery or trees. Again the density of vegetation depends on the years under protection. If it has been protected for 3 to 5 years, it has sparse to dense shrubbery. If it has been protected for more than 10 or 15 years, a kind of dwarf forest is developed. These slopes are in regenerating states and have great potential for restoration of forests.

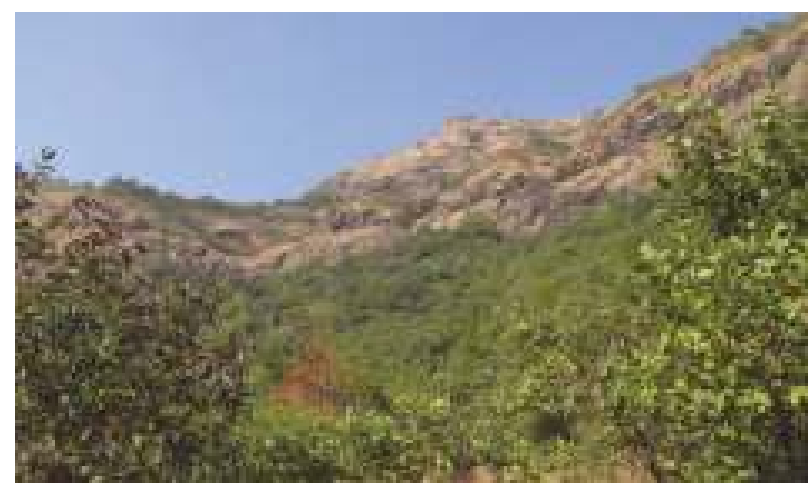

Steep slopes with forests @ Bambharde, Mulshi

4. Cliff or Cliffside rock fall areas - These areas are very near to the mountain tops with vertical cliffs and are the most inaccessible areas. Due to its geological pattern, heavy rainfall, wind pressures, etc., big boulders escape and fall on the narrow belt just below such cliffs, so the name rock-fall areas. This area has been protected since centuries. So it experiences a mature, tall evergreen forest with big, old growth trees. These are specialist species which need a special micro-climate that is maintained just because of inaccessibility. In certain patches this 


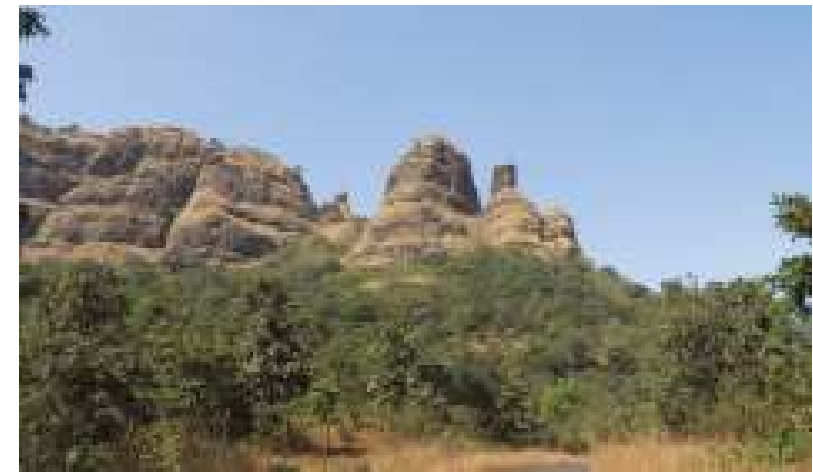

Cliffside rockfall areas@ Ghutke, Mulshi

kind of vegetation is also seen on gradual or steep slopes primarily because those are owned by the forest department. This indicates that the entire landscape can have such tall mature forest if protection is assured. Interestingly, many Sacred Groves are located in these patches. Sacred groves are the forest patches preserved after the name of some deity.

5. Plateaus - Plateaus are located at various elevations in Western Ghats. If any plateau is nearby any settlement and has a good soil profile, it is seen to be under cultivation of either rice or hill millets. If it is a rocky outcrop, it is mainly used for grazing cattle. Such areas mainly have seasonal grass or herbaceous cover, with endemic species.

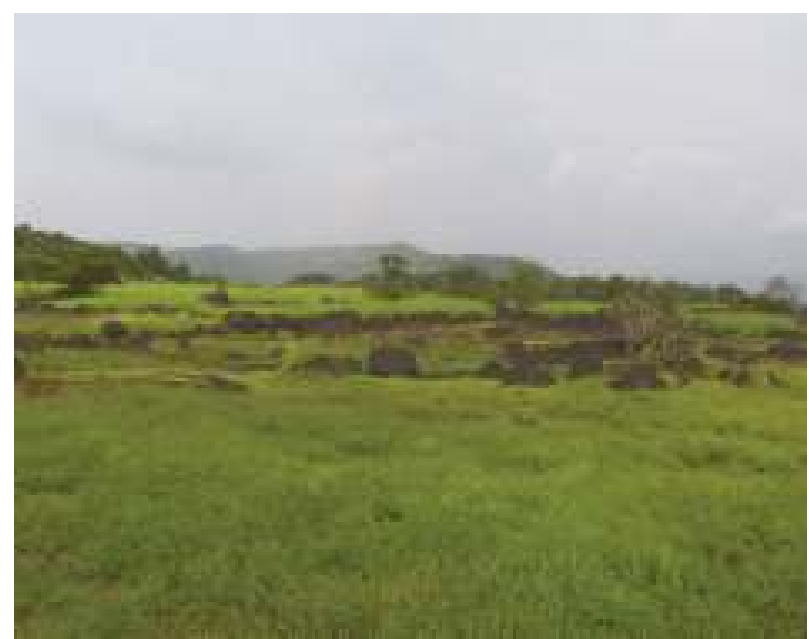

Plateau@ Kurtwadi, Panshet catchment

In short, all these land classes are used by local people as per their need and convenience. Human interference is altering the status of natural resources and biodiversity in the surroundings.

\section{Analysis of landscape with respect to biodiversity}

Biodiversity is an expression of - 1. Climatic factors, and 2. Current ecological processes shaped by current practices on the land. It is observed that biodiversity changes as per the land class and its use or degree of degradation and/or protection. So biodiversity can be used easily to judge the status of the landscape elements. Due to a definite traditional land use pattern in NWGs, broadly six seral stages or vegetation classes are observed, namely, Rocky outcrops with seasonal herbs, Scrub with intermittent coppiced trees, Dense shrubbery, Dwarf canopy forests, Tall mature forests and special Riparian vegetation along with four human induced land elements namely paddy, settlements, roads and modern developmental projects.

Associations of faunal groups, especially birds, are used as an additional indicator. Indicator species can be called as 'habitat specialist' species pertaining to one particular habitat whereas 'habitat generalist' species occur commonly in many habitats.

1. Rocky outcrops : Rocky outcrops are a special land class in NWGs, and is an important habitat to many endemic, rare and endangered species. These are either lateritic or basaltic in origin. Scarcity of soil and harsh physical conditions lead to formation of vegetation dominated by grasses and herbaceous flora along with habitat-specialist amphibians and reptiles. (Watve, Rocky Plateaus, 2010) Also they offer a number of ecological services to nearby villagers. Being reserves of bauxite, the Lateritic plateaus are under serious

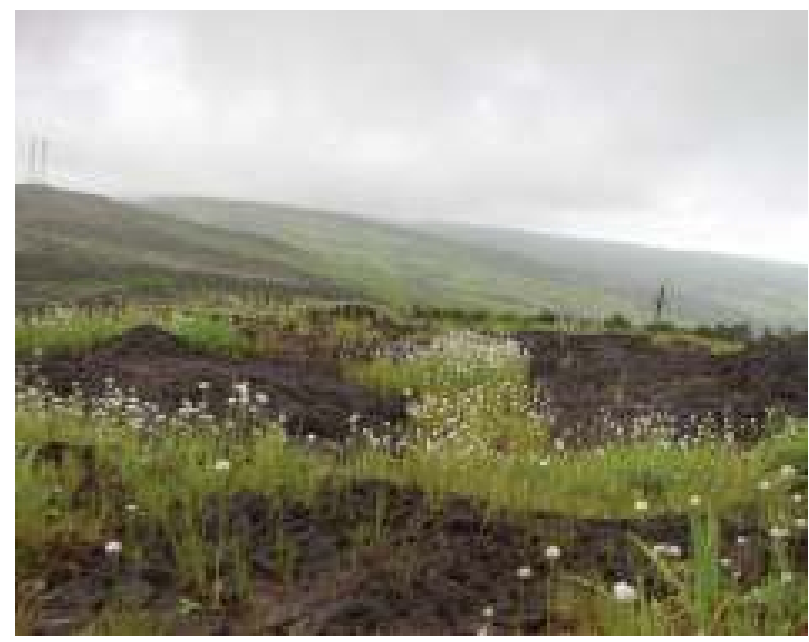

Lateritic plateau, Chalkewadi 
threat due to mining.

Biodiversity changes significantly as per seasons. Because of monsoon, regeneration of ephemerals, i.e. plants with short life cycle of 2 to 4 months, is initiated. They are mostly mass blooming herbs with bright colors favoring insect pollination. So monsoon brings life to these plateaus. After monsoon, all these ephemerals die and their seeds remain dormant till next monsoon.

Dominant Plants in the rocky outcrops include herbs like Eriocaulon, Utricularia, Smithia, Impatiens, Murdannia, Neanotis, Habenaria etc.

Birds like the Pied Bushchat and Malabar Lark are seen throughout the year whereas specialist species like Horse shoe shrimp, Caecillian are observed during monsoon.

2. Scrub : Scrub dominated by grasslands are seen mostly on gradual slopes near the valley bottom. Intermittent coppiced trees, as an indication of earlier canopy forests, are seen all over these areas. Being most exploited and disturbed, these areas have mostly hardy species indicating degradation.

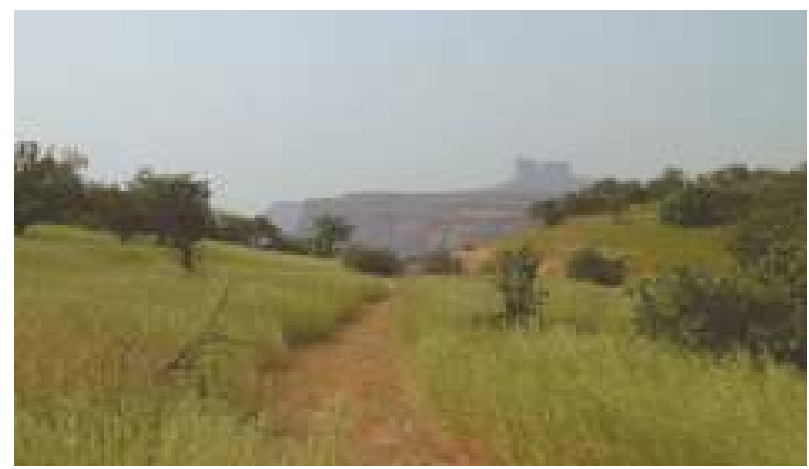

Open grassland with scrub near Tailbela fort, Mulshi

Dominant plants include grasses like Themeda, Heteropogon, Apluda along with shrubs of Carrisa congesta, Meyna laxiflora, Gnidia gluaca, and sparse trees of Terminalia elliptica, Mangifera indica, Syzygium cuminii etc.

Birds like the Pied Bushchat, Sunbirds, and Bulbuls are easily seen.

These are all habitat-generalist species being established in the newly generated habitat than the original habitat.

3. Dense shrubbery: Dense shrubbery with intermittent trees is observed on part of the gradual slopes and on the transitional belt in between gradual and steep slopes. These are old shifting cultivation patches, which have been left fallow

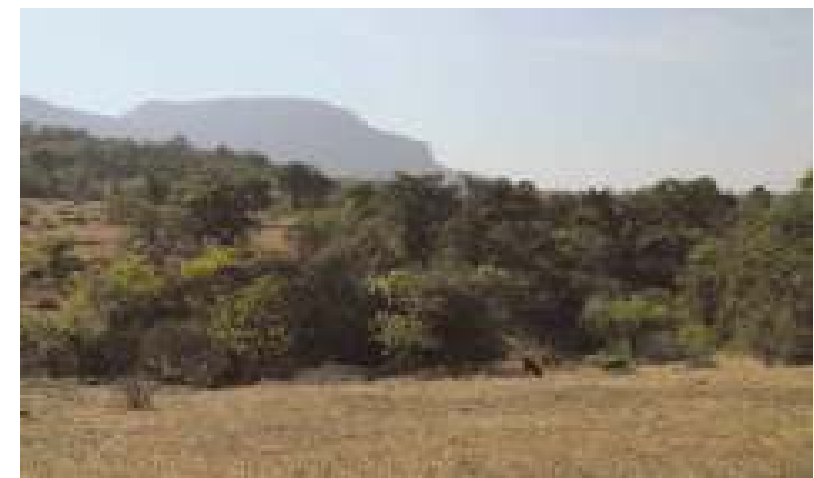

Dense shrubbery, Pavana catchment

since 7 to 10 years and have habitat- generalist species, with a dominance of shrubs.

Plants here include Carissa congesta, Meyna laxiflora, Gnidia gluaca, Catunaregam spinosa, and trees like Terminalia elliptica, Bridelia retusa, Syzygium cuminii, Lagerstroemia lanceolata, Ixora brachiata etc.

Birds include Common Chifchaf, Jungle Babbler, Brown Cheeked Fulvetta, Red whiskered Bulbul, Paradise Flycatcher along with all the common birds seen in grasslands.

These are termed as regenerating patches, because the vegetation structure is in a regenerating state and is a potential stage for restoration of forests. Occasionally found floral and faunal species are also seen in such patches.

4. Dwarf canopy forests : The dwarf canopy forest which is mostly seen on gradual to steep slopes includes habitat generalist tree species with much more density of trees. These are old shifting cultivation patches, which are left fallow for more than 10 years. Their composition is more or less similar to dense shrubbery except for the increased density of trees forming dwarf forest canopy, with few additional tree species pertaining to canopy.

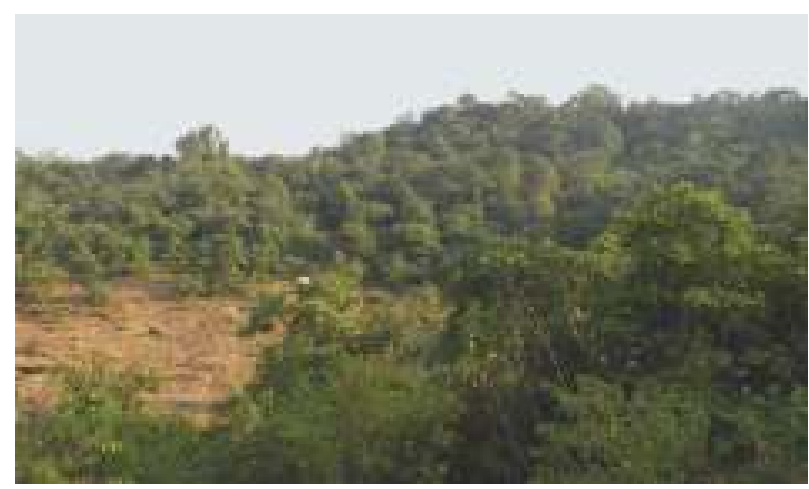

Canopy forests@ Koyna catchment 
Plants include Terminalia elliptica, Terminalia chebula, Syzygium cuminii, Lagerstroemia lanceolata, Ixora brachiata, Ficus racemosa, Memecylon umbellatum, Xantolis tomentosa etc.

Birds include Yellow Browed Bulbul, Paradise Flycatcher, Black naped Monarch, Large Green Barbet, Orange Headed Ground Thrush, White Bellied Blue Flycatcher, Black eagle etc.

These patches being protected for a long period are now serving as safe sites for shy and specialist birds like Grey Jungle fowl, Flycatchers etc.

5. Tall mature forests: Tall Mature Forest is seen along cliffs or steep slopes with rock fall. All Habitat-specialist species are seen in these protected areas as they are saved from cutting, fire, cattle interference, or any other human interference. As the name indicates, it contains specialist biodiversity and is very delicate. If their habitats are disturbed, such species may vanish or leave that habitat.

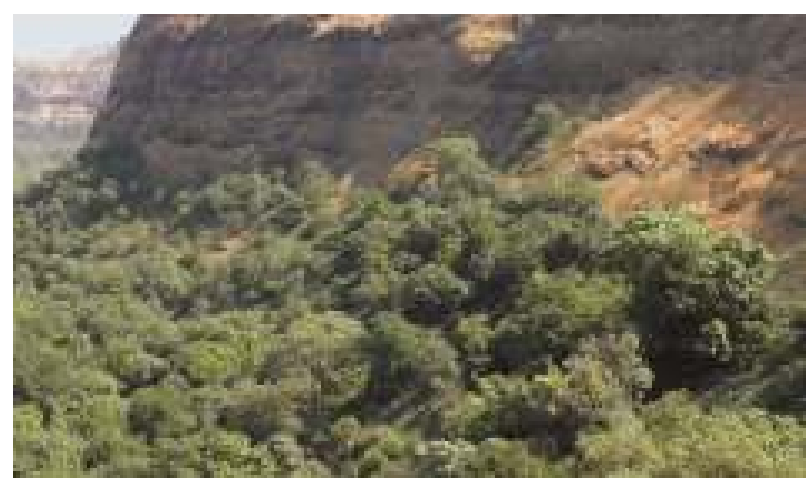

Mature forests @ Ghandad, Mulshi

Plants include Olea dioica, Dimocarpus longan, Ficus nervosa, Garcinia talbotii, Beilschmedia dalzelli, Gnetum ula, Holigarna grahamii, Entada rheedii, Tetrameles nudiflora, Knema attenuata, etc.

Birds include Yellow Browed Bulbul, Large Green Barbet, Black bulbul, Malabar Whistling Thrush, White Bellied Blue Flycatcher, White Rumped Shama, Eurasian Eagle owl, Besra, Great Pied Hornbill etc.

6. Riparian vegetation: Riparian vegetation i.e. vegetation along stream courses is very significant from the ecological point of view. Those are the most potential corridors in a degraded landscape. Corridors are the vegetated belts connecting two patches in a landscape. They also host specialist species. Being a difficult area for any human use, it is a safe site for many animals. Many specialist

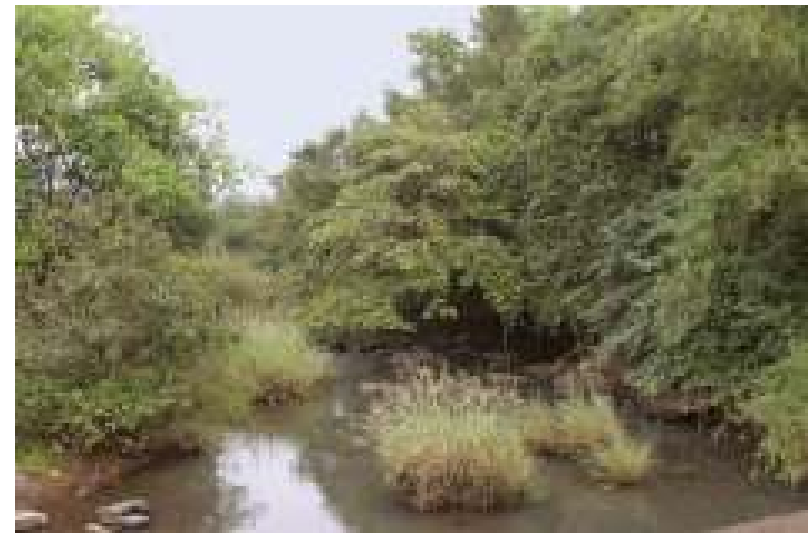

Riparian forests, Tamhini, Mulshi

orchids are seen in such patches, along with endemic species of amphibians and reptiles. These patches are excellent nesting sites for many birds. They also contain larval host plants for many butterflies.

The plant composition is similar to the seral stages Dwarf canopy forests and Mature forests, with dominance of Syzygium cuminii, Ficus racemosa, Dimocarpus longan, Xantolis tomentosa, Cinnamomum zeylanica, Ancistrocladus heyneanus etc.

Birds include Large Green Barbet, Malabar Whistling Thrush, White Bellied Blue Flycatcher, White Rumped Shama, Ultramarine flycatcher, etc.

Endemic Amphibians include Reddish burrowing frog - Fejervarya rufescens, Humayun's Night Frog Nyctibatrachus humayuni, Marbled Ramanella Ramanella mormorata along with Leaping Frog, Fungoid frog, Kokan Bush frog etc.

All the above vegetation classes have some 15 - 20 commonly found species of mammals distributed more or less throughout the landscape. Among these, Striped Hyena, Leoprad and Pangolin are Near Threatened (NT) and Sambar deer and Indian Bison are Vulnerable (V) as per IUCN. Jackal, Porcupine, Barking deer, Wild Boar, Civet, Bats, Mongoose are among the commonly seen species. Keystone species like Malabar Giant squirrel or Slender Lorris are seen only in mature or canopy forest patches and their habitat is continuously stressed and shrinking.

In addition to the above vegetation classes, the following four land elements are worth considering. These are induced due to mainly intense human interference, as compared to all above.

1. Paddy: During the monsoon season, paddy fields support minimal biodiversity like a few amphibians and reptiles. But once the crop is harvested many ephemerals i.e. seasonal herbs 
regenerate and attract many bees and other insects. A few paddy fields, carved in riparian patches have active sub-surface water flows till summer. They form a nice moist ground habitat for insects especially during dry conditions. Many of these herbs like Alternanthera, Blumea, Hygrophila etc. flower after monsoon and serve as fantastic food plants for insects.

Traditionally, paddy fields were not harming or changing the native/original ecosystems beyond certain extent. It had its own threshold governed by controlled population needs and physical limitation of human labour-based agriculture. But with technology like excavators reaching out to the wadis, people prefer to terrace on bigger areas, which is not appropriate in hilly terrain. Obviously, it leads to soil erosion and landslides, which needs serious attention.

2. Settlements : As mentioned initially, all catchments of dams have settlements on lower or upper slopes. Often, there is a certain arrangement of these settlements as per the caste system. Obviously, use of resources from the surrounding forest gets more or less distributed amongst them. Many a times old settlements have old growth trees around them namely Mango, Jackfruit, Jamun, Kokam etc. which also serves as habitat for many animals, especially birds like Barbet and Thrushes, along with other common species like Bulbul and Sunbirds. Ecologically appropriate traditional housing makes modern engineers marvel at how a grass thatch can waterproof a hut. But now the locals, thanks to their urban aspirations, do not wish to continue to live in those grass-thatch houses, but choose to build pakka makan - cement concrete houses. Their children, who have migrated to cities and earning a better income, are getting enough money to transport modern materials from outside and build such houses. Also many locals are selling out lands, especially fallow lands, to urbanites and in return getting the money to live an urban lifestyle independent of forests around. A great shift can be seen from earlier forest-dependant livelihood to the money-driven market economy. Often, only elders and possibly women, are seen to be living in these villages. Young men are migrating towards the nearby taluka place or city in search of jobs. Such settlements lack habitat for biodiversity, being human-dominated areas.

3. Roads: Roads has been an instrumental tool to connect all remote areas to urban areas. Ring roads along the catchments have helped contractors to enter the forest, buy it for timber or non-timber value or make it into coal and sell it in the cities. Roads have fragmented the good forests patches, even Sacred Groves, at some places. Roads have dissected corridors of many animals. If not engineered properly, roads prove to be the cause for instability of any slope, ultimately causing landslides or erosion.

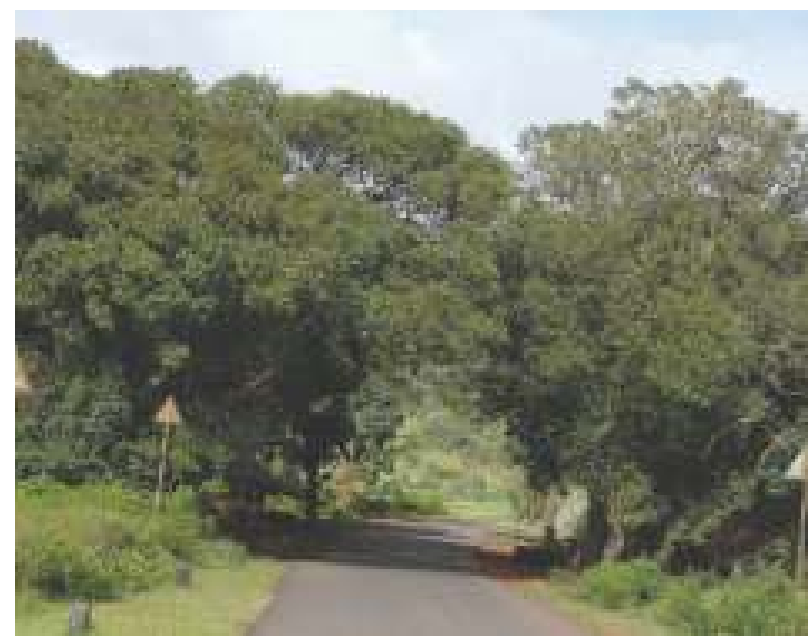

Road through Sacred Grove @ Chalakewadi, Satara

4. Modern developmental projects : Apart from all such human-induced pressures on the landscape, another considerable stressor, which is multiplying the adverse impact many times, is modern development in the form of farm houses, townships, mining, or power generation projects. This kind of pressure is severe in some pockets of the NWG and sprawling all over the landscape at quite a fast rate.

Based on the current developmental trends, the government's perspective, standards of governance, and current policies, it seems difficult to stop such kind of development completely. The only way is to offer management strategies considering all of the above and set up a system to implement such strategies step by step.

\section{Management}

Protection and conservation of the forest is the principal management option in Northwest Western Ghats. (Gole, Survey of birds of Bhimashankar wildlife sanctuary and formulation of managment guidlines for their protection, 2000). However, the forest here is distributed in patches and is not a continuous habitat. Hence, management needs to 


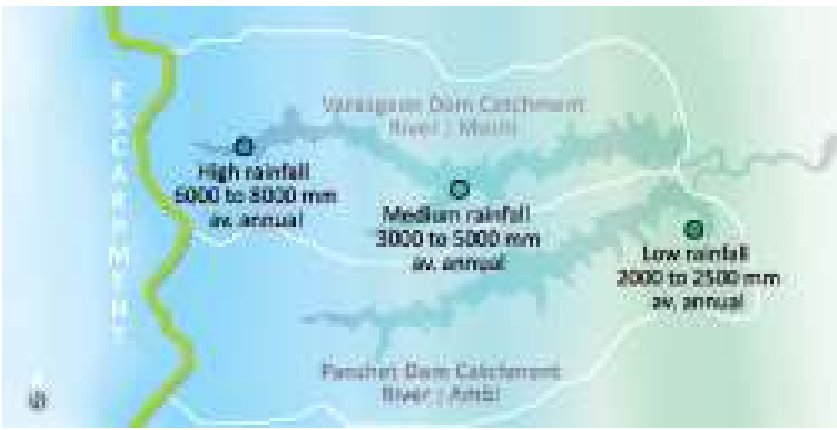

Diagram showing indicative approximate rainfall zones within dam catchments

have the landscape perspective. The entire landscape can be looked upon as a mosaic of habitats. There are interactions among different habitats in terms of energy, mineral nutrients and life forms. The degree to which each habitat is exposed to threats also varies depending on anthropogenic, climatic and erosive processes. These will affect movement of life forms, availability of life support to them and their reproductive potential.

We recommend that such landscape-based management take into account key dimensions like rainfall zones, river catchments, and land classes.

\section{Macro - Management :}

Strategy as per river catchments, rainfall zones and fragility of ecosystems within catchment:

As discussed earlier, there are a large number of river catchments in NWGs due the several dams that have been built, particularly on rivers flowing East. Thus it may be appropriate to shape management strategy based on ecological status of each river catchment. A common feature of most catchments in NWG is rainfall pattern and alignment of backwaters, mostly East-to-West and almost at the same longitude. (Gadgil, 1979). All the dam walls are built in relatively low rainfall area of approx. $2000 \mathrm{~mm}$ a. a. (average annual). Rainfall increases drastically towards West of these dams, towards crest line up to $8000 \mathrm{~mm}$ a. a. So, on an average, three rainfall zones are observed within catchments,

- Relatively low rainfall region with $2000 \mathrm{~mm}$ a. a.

- Medium rainfall region with $4000 \mathrm{~mm}$ a. a. and

- High rainfall region with 6000 to $8000 \mathrm{~mm}$ a. a. at the escarpment.

Biodiversity and ecological processes around the catchment are influenced by this rainfall pattern and also the current socio-cultural practices. High rainfall zone is terminated into the Western escarpment. This zone being most fragile ecosystem needs a carefully considered management treatment. It also serves as a corridor for the movement of higher fauna like Tigers, Leopards, Wild dogs etc. and supports maximum specialist species within any given catchment. So, this zone needs total protection and should be free from any human interference. Ideally it should be notified as a protected area or sanctuary and needs to be managed by the forest department.

\section{Management as per land class :}

In light of the discussion in sub-chapters I, II and III, it can be said that because of varied land classes, its use by local people and current seral stage, one single strategy for conservation may not be enough.

Ecological role and potential of each land class needs to be addressed to evolve management strategy. Landscape-based management should favor following three key elements :

1. It should facilitate linkages between different habitat segments : Scattered patches of the same habitat as well as between different habitat.

2. It should reduce adverse effects of climatic and erosive processes and

3. It should control and streamline anthropogenic activities and pressures

Let us now look at management of the landscape by specific land classes. In each case let us identify the main management objective and provide a strategy to address it.

\section{Mountain Tops, Plateaus, and Cliffs :}

- Objective: To create sponge effect i.e. to restore perennial semi evergreen forests on mountain tops, and preserve it as the source of rivers. The quantity of rain that falls in the humid tropics depends on several factors and forest cover is one of them (MeherHomji, 1991). Well-stocked forests cause precipitation on mountain tops and let it percolate in the soil effectively than an open grassland patch.

- Management strategy: Total protection and conservation, Restricted entry. These mountain tops should be totally protected from biotic interferences like cutting for fuel wood or grazing by cattle. No fire should be initiated in this zone.

\section{Upper Slopes :}

- Objective: To stop erosion and arrest soil and moisture, restore habitat and species diversity. These areas, being mostly steep slopes, need special care to control soil erosion, landslides etc. Also being difficult sites for 
human beings, they have the potential to serve as safe site for non-human beings.

- Management strategy: Protection from grazing and fire, restoration techniques. (Illustrated in next subchapter) Development like roads or infrastructure should not be carried out in these stretches. Assured protection along with restoration techniques, would ensure improvement in stabilization of physical landscape features along with habitat and species diversity.

\section{Lower slopes :}

- Objective: To restore these areas to a mosaic of habitats useful for both non-humans and humans. Lower slopes being nearer to human settlements, are worth converting into forests which would provide various products and services to the local people.

- Management strategy : Restoration techniques. Alternative supportive livelihood systems for locals through management of vegetation and plantations, Grazing grounds for cattle. Looking at the current status of these slopes, they need to be rejuvenated to have forests. Initially restoration techniques can be implemented to restore poor soil and put back nutrients. Later on, plantation of useful native plants can be done along with protection for natural regeneration. Looking at the bad effects of freegrazing cattle all over the landscape, an area can be allocated for cattle as 'grazing ground' and practices like rotational grazing can be carried out.

\section{Streams and Riparian vegetation:}

- Objective : To improve landscape functioning through corridor development, recharging hyporheic zone, conservation of specialist species. Streams are the most potential landscape element serving as corridors for movement of materials and organisms. Also due to water availability and special micro-climates, many specialist species are able to thrive here better than the degraded surroundings.

- Management strategy : Protection and restoration techniques. A complete ban on interventions which would modify the physical character of the stream is essential. Stream restoration should be carried out to ensure smooth functioning of physical processes and enhancement in biotic community within streams. Riparian zone also needs to be protected and enhanced with the help of plantation of riparian species.

\section{Valley bottom: Paddy and Human Settlements}

- Objective : Improve the ecological potential of this matrix to mosaics. Matrix is the area within a landscape which is modified from its natural condition due to human intervention. Mosaic is the same natural area without such disturbance. Such newly modified areas should mimic the original mosaics, wherever possible. This would create some room for local biodiversity totally but keep some room for them even within disturbed areas.

- Management strategy : Construction in human settlements should be preferably with local materials, Camouflaging should be the main attribute which should be applied to all possible human elements. e.g. houses made up of stone and mud and thatch roof camouflages well in the surrounding than conventional modern cement houses. Roads should be restricted till the valley or lower slopes only along with plantations of appropriate species. Roads if cut through the steep slopes disturbs the stability of the slopes. It becomes heavy on maintenance, so roads through upper catchments are bad for economy as well as ecology. Roads can be converted into potential corridors by planting avenue trees on both sides. Agriculture bunds also should have intermittent old growth trees to serve as 'stepping stones' for birds and other fauna.

6. Special guidelines for modern development like resorts, farmhouses, and townships:

- While planning, such schemes must consider the landscape structure, local ecological conditions and distribution of biodiversity.

- The Master Plan of such schemes must be based on ecological assessment of the area and favoring the three key elements mentioned above. 1. It should facilitate linkages between different habitat segments. 2. It should reduce adverse effects of climatic and erosive processes and 3 . It should control and streamline anthropogenic activities and pressures.

- There should be some kind of strictly enforced restriction on plot size ( 1 acre to 10 acre depending on status of landscape : If landscape is forested with good corridors, big size plots with minimum 10 acre would assure protection to large chunks instead of fragmentation of the same in smaller plots with an acre. If landscape is too open and devoid of any vegetation and habitats, plot area could be 1 acre. This suggestion is based on market trends and feasibility), length and reach of roads and material use. Local materials harvested sustainably or materials with zero or minimum embodied energy should be used. 
- Guidelines and incentives for new residents to be responsible for conservation on an ongoing basis, and penalties for failure.

- Solid and liquid waste management policies and systems to implement and monitor their execution.

- A Biodiversity Register for the landscape should be prepared every three years. Experts should review it and suggest actions to conserve species if required.

- Land acquisition in such areas should not be left to market forces alone. When market dynamics are left to rule, land from local people tends to get acquired at attractive prices for modern development projects. The monetary and lifestyle upliftment expectations of local people should be met by the policy makers through other means, including nature-centric economic policies and educational and job opportunities. Changes in land use should be slowed down with appropriate voice provided to conservationists and ecological experts. The government and policy makers need to change their perspective from an agent of modern development to also additionally include being stewards of natural resources and ecosystems. Farreaching, values-based reforms in land acquisition, real estate industry ethics, taxation and environmental assessment of projects are essential to protect these environmentally sensitive landscapes for the sake of our future generations.

\section{Conservation \& Restoration techniques and activities to support ecological management :}

1. Protection: Social fencing, dry fence, live hedge, fire lines.

Protection can be easily assured with the help of traditional methods like dry fence of thorny plants and live hedge of hardy shrubs which cattle do not eat. Such hedges also provide safe refuge for tiny wildlife like insects and birds. Social fencing (i.e. protecting an area with the common consent of the locals) is also an effective tool for protection.

2. Restrictions and controls : At any given time and for any particular area there could be a number of restrictions as a part of forest management. e.g. Ban and restriction on collection of fuel wood, minor forest produce, grazing, vehicular movement, illumination, noise, plantations of non-native species etc. are necessary to initiate and protect ecological processes which are necessary to start ecological succession on degraded lands. Restriction on cutting for fuel wood would stop coppicing of the same tree every year and would ensure its regular cycles of flowering, fruiting and seeding every year. Ban on grazing would assure protection to natural regeneration. Ban or control on street lights or any illumination along with noise control during night is necessary for movement of nocturnal animals. Total ban on introduction of non native species would save the integrity of ecosystems; otherwise it may invade large areas.

3. Provision of alternatives: Common grazing grounds, Energy plantations, etc.

Whenever restrictions are applied on usage of resources, local people may suffer as their daily needs for fuel and fodder may not be met. Alternatives need to be provided to them to be able to continue their lifestyle in a better way. e.g. If a ban on wood cutting is applied, plantations of fuel wood species should be done at village level to fulfill the fuel need. Common grazing grounds would provide palatable fodder for cattle. This practice of reserving gayran (grazing land) has been there in many parts of Maharashtra. It needs to be revived.

4. Monitoring: Weather stations, Old growth trees, Biodiversity.

Regular monitoring should be done for certain parameters like rainfall, temperatures, humidity, soil conditions, etc. Also certain ecologically sensitive features like old growth trees, springs should be monitored to record visits of fauna or to know associations. Biodiversity registers should be prepared at regular interval to record change in species especially indicator or specialist species.

5. Waste management : Solid and liquid waste needs to be segregated and disposed off in an ecologically appropriate and energy friendly way. e.g. Biodegradable solid waste can be composted into fertilizer, Liquid waste can be treated using botanical systems like Root zone treatment systems. Non-biodegradable waste should be sent for recycling. Systems to follow waste management policies should be in place.

6. Special management for streams and large water bodies if any

As mentioned in the earlier section, streams need special management, so do any other water bodies like pond, lake, wetlands. All these smaller units of ecosystem need to be managed after thorough assessment.

7. Restoration techniques :

$i$. Soil and moisture conservation through stone bunding, ponds etc. Simple time tested solutions can be offered to arrest soil and moisture like 
loose boulder bunds, trench cum mounds etc.

ii. Site specific treatment for erosional features : Erosional features needs to be treated as per the status and need. E.g. headward erosion, erosional gullies, landslides etc. Each of these would have different treatment depending on various physical attributes. Soft techniques like plantation of shrubs or putting one or two stones would be sufficient for gullies. But landslides may need attention from expert engineers to calculate load of soil, know velocity of water and then design appropriate retaining structure.

iii. Conservation of interface between two habitats : Ecotone to Ecocline: Many times there is sudden change inbetween two habitats known as ecotone. E.g. forest neighboring a grasslands patch. Sometimes the changes across habitats are gradual and this is known as ecocline. E.g. A mature forest a has buffer of tall canopy trees followed by shrubbery and then grasslands. An ecocline condition is preferred over an ecotone condition. Management should favor development and protection towards such ecocline conditions.
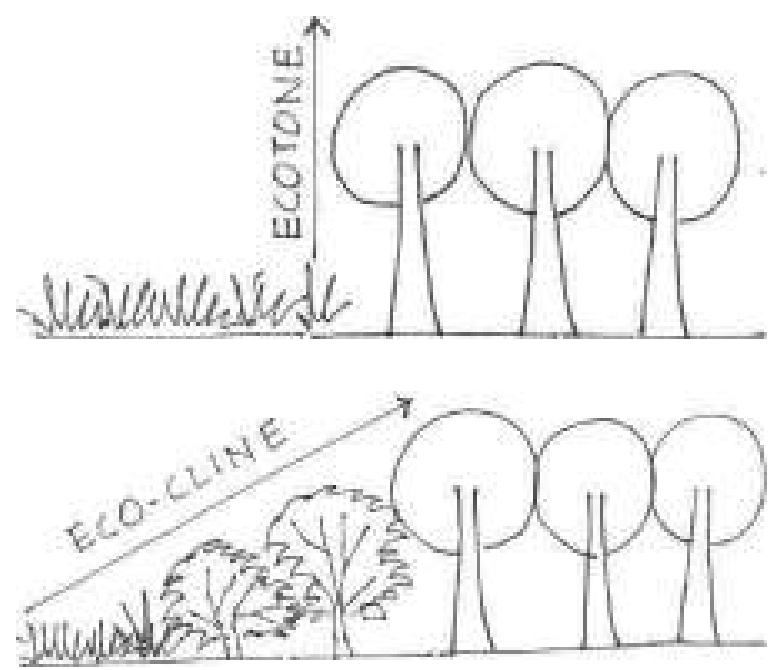

iv. Plantations : Along roads, edges of fields, hedges, bird attracting parasites, Nursery : Plantations of native species should be done depending on the current status of the land. Best potential places for such plantations are roadsides, edges of fields etc. Also shrubs could be planted as hedge row. Bird-attracting parasites on trees may need special protection.

\section{Bibliography}

Champion, H. G., \& Seth, S. K. (2005). A revised survey of forest types of India. Dehradun: Natraj Publications.

Gadgil, M. (1979). Hills, Dams and Forests. Bangalore: IISC.

Gazeteer department, (1885). Gazeteer of Bombay Presidency, Poona district, VOLUME XVIII, PART I. Govt. of Maharashtra.

Ghate, U., Bhagwat, S., Gokhale, Y., \& Gour Broome, V. (1997). Assessing the tropical forest plant diversity: A case study from Western Ghats, India. International Journal of Ecology and Environmental Sciences 23 .

Gole, P. (1985). An Enquiry into the status of animal and plant life in critical areas of Western Ghats in order to evolve a plan to conserve their biological diversity. Ecological Society.

Gole, P. (2000). Survey of birds of Bhimashankar wildlife sanctuary and formulation of managment guidlines for their protection. Ecological Society.

Kodandapani, N., Cochrane, M., \& Sukumar. (2004). Conservation threat of increasing fire frequencies in Western Ghats. Conservation Biology, Volume 18. No. 6.

KSR Murthy, et. al. (2012). Checklist and conservation strategies of genus ceropegia in India. International Journal of Biodiversity and Conservation. Vol. 4(8), pp. 304-315.

Meher-Homji, V. M. (1991). Probable impact of deforestation on hydrological processes. . Climatic Change 19, 163-73.

Negi, S. S. (1993). Rare and threatened plants. In S. S. Negi, Biodiversity and its conservation in India (pp. 150-151). New Delhi: Indus Publishing Company.

Norman, M., Meittermeir, R., Meittermeir, C., da Fonseca, G., \& Kent, J. (1999). Biodiveristy hotspots for conservation priorities. Nature 403 , 853-858.

Watve, A. (2010). Rocky Plateaus. WGEEP.

Watve, A., Gandhe, R., \& Gandhe, K. (n.d.). Vegetation Structure and Composition of Semi evrgreen forest fragments in Mulshi area of Northern Western Ghats. Annals of Forestry 11.

Most of the conclusions and arguments in this article are based on the actual field work done by the author during last 12 years, in Northern Western Ghats. 